\title{
Geochemical insights into shallow magmatic processes and tranisitioning eruption styles, Ambae, Vanuatu
}

\author{
N. Collins1*, M. C. Rowe1, G. KILgOUR2, A. R. L. \\ NICHOLS3
}

1School of Environment, The University of Auckland, New

Zealand (*correspondence: ncol839@aucklanduni.ac.nz) ${ }_{2}$ GNS Science, Wairakei Research Centre, Taupo, New

Zealand

${ }_{3}$ School of Earth and Environment, University of Canterbury, Christchurch, New Zealand

Ambae is the largest basaltic volcano in the Vanuatu Arc with eruptive activity having occurred at both the summit and along the island's prominent rift zone. Rift volcanism is characterised by "dry" strombolian eruptions and phreatomagmatic activity where the rift enters the sea. Devil's Rock is a prominent outcrop on the SW coast of Ambae. Eruptive deposits here record transitions in style from strombolian to phreatomagmatic and contain abundant olivine- and pyroxene- hosted glassy melt inclusions. Highly variable groundmass crystallinities also provide excellent material to assess the underlying cause/s of eruptive behaviour, and are used to explain how magma is generated and modified beneath the island.

Ambae melt compositions evolve predominantly through fractional crystallisation. However, in some cases the compositions are too diverse to be explained by partial melting of a single parental source. We use mineral-melt disequilibria along with olivine and pyroxnene phenocryst textures to show that mixing between separate magma batches occurred with varying levels of differentiation. Similarities in $\mathrm{H}_{2} \mathrm{O}, \mathrm{CO}_{2}$ and $\mathrm{S}$ concentrations between Devil's Rock melt inclusions and groundmass glass with those erupted during the 2017-2018 summit eruptions highlight the possibility of a shared magmatic reservoir beneath Ambae.

The transition between strombolian and phreatomagmatic activity at Devil's Rock is accompanied by minor changes in volatile abundance most likely driven by the presence of external water. This is supported by changes in groundmass crystallinity and porosity between eruption styles. Groundmass and melt inclusion textures show strong modification post-eruption which is attributed to magma cooling rates and surface volatile degassing. This has allowed the identification of at least four separate eruptive phases, with greater magma- water interaction through time. 